\title{
A resiliência do Estado Nacional diante da globalização
}

\author{
RUBENS RICUPERO
}

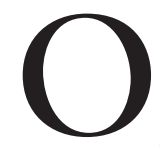

S ESTUDOS do seminário que inspirou o dossiê "Nação/Nacionalismo" deste número de ESTUDOS AVANÇADOS são todos dedicados à análise de experiências européias, com exceção de artigo sobre Israel. Mesmo esse foi escrito por um europeu, assim como os demais.

A nacionalidade dos autores não deixa de ser uma limitação, quando se leva em conta a abrangência universal do tema escolhido - a nação, o nacionalismo - sem adjetivos. Não há trabalhos realizados a partir de outras perspectivas, da Ásia, da África, da América do Norte ou do Sul.

Sanar a lacuna terá sido um dos motivos que levaram a revista a adotar o tema, ampliando-lhe o tratamento. $\mathrm{O}$ que se justifica plenamente, posto que, em matéria de nação e/ou nacionalismo, a Europa se afasta da regra geral pelo seu excepcionalismo.

Os europeus inventaram o Estado-nação e o nacionalismo moderno juntamente com os fundadores da independência americana. Na Europa, porém, a criação se transformou em monstro, voltando-se, no século XX, contra os criadores e provocando rejeição crítica de que não se encontram paralelos em outras regiões ou continentes. A União Européia (UE) representa atualmente o único exemplo bem-sucedido (ainda incompleto) de esforço com duração de mais de meio século para edificar estrutura estatal que transcende o Estado-nação. A tendência se deve justamente à traumática experiência dos europeus com o monstruoso nacionalismo das duas guerras mundiais e ao desejo de reverter esse processo autodestrutivo.

É por esse motivo que se aconselha alargar o foco do exame, a fim de evitar aproximação parcial e incompleta. Tentarei, de minha parte, dar contribuição nesse sentido, com duas ressalvas. A primeira é que não me ocuparei do que o professor Paulo Butti de Lima chama, na "Introdução", de "sentimentos" nacionais.

A segunda se refere à nomenclatura, nem sempre preocupada, nos estudos do dossiê, em distinguir com precisão o conceito de "nação" do de "Estado Nacional". Com freqüência, quando se fala de nação, a referência é mais ao Estado-nação propriamente dito, como fica claro da "Introdução", ao mencionar os "processos históricos de afirmação das nações no mundo moderno e contemporâneo". Afirmação que se fez pela organização das nações em Estados Nacionais, sobretudo a partir da Revolução Francesa. 
Nessa linha, a abordagem a que tenciono recorrer é a da teoria das relações internacionais, que valoriza o papel do Estado-nação como ator principal de sistema internacional formado por unidades similares. A importância desse enfoque não implica ignorar-lhe certas limitações, como as apontadas por Giddens (1996, p.65-7).

O enfraquecimento do Estado Nacional por obra da globalização vem sendo anunciado em farta literatura, de que se encontra boa amostra em Habermas (2001). Sem desconhecer o valor de tais argumentos, buscarei mostrar que o Estado Nacional tem sido capaz de surpreendente resiliência, no sentido figurado do Dicionário Honaiss: "capacidade de se recobrar facilmente ou se adaptar à má sorte ou às mudanças”.

Para isso, em complementação ao tipo de narrativa empregado nas comunicações ao seminário, talvez seja útil um levantamento empírico de qual tem sido a experiência real das últimas décadas em matéria de Estado-nação. A lente de exame se abriria, assim, em ângulo muito mais largo do que o europeu ou ocidental, tentando abarcar visão tão universal quanto possível das tendências nessa matéria, numa espécie de geografia política mundial do moderno Estado Nacional.

\section{A "balcanização" do planeta}

No momento em que escrevo (fevereiro de 2008), uma das novas crises da agenda internacional é a proclamação de direito do Kosovo como Estado independente da Sérvia, o que ele já é de fato. Dois anos atrás, foi a vez de Montenegro. No breve lapso de pouco mais de dez anos, a península iugoslava viu surgirem sete Estados onde existia apenas a Federação Iugoslava. Pouco antes, a desintegração da União Soviética produzira quinze Estados a partir de um só.

A "balcanização", após fazer o giro do mundo, volta assim aos Bálcãs de origem. Alguns especialistas em relações internacionais foram buscar essa expressão antiga para descrever a verdadeira proliferação de Estados, que se iniciou no século XX e se prolonga até hoje. Um século antes, havia-se registrado notável contração no número de unidades soberanas por uma dupla causa: de um lado, a unificação da Alemanha e da Itália; de outro, a expansão do imperialismo europeu na África e na Ásia, eliminando inúmeras entidades autônomas anteriores. A exceção quanto à criação de Estados tinha sido a independência da América Latina, em especial a fragmentação da América espanhola.

Recuando-se um pouco mais, até a Europa dos séculos XVII e XVIII, contavam-se quase quinhentas unidades correspondentes ao gênero que precedeu o Estado Nacional, o de natureza territorial, tal como consagrado pela Paz de Westfália (1648). Depois das guerras da Revolução Francesa e de Napoleão, sobraram, no Congresso de Viena, aproximadamente trinta Estados europeus, dos quais eram poucos os genuínos Estados Nacionais como a França ou a Inglaterra, conservando ainda alguns a natureza de Estados multinacionais ligados pelo vínculo da dinastia comum. 
Esses impérios crescentemente anacrônicos - o Turco-Otomano, o Czarista, o Austro-Húngaro - vão desaparecer na Primeira Guerra Mundial, dando nascimento a numerosos Estados relativamente mais homogêneos, do ponto de vista da constituição nacional, na Europa Central, Oriental, Balcânica e no Médio Oriente. Desde então, não cessou de acentuar-se a tendência à proliferação de Estados, mediante a grande vaga de descolonização na Ásia, no Caribe e na África. Somente nesta última, os Estados independentes passaram de dois ou três (Egito, União Sul-Africana, Etiópia antes da ocupação italiana) a mais de cinqüenta.

Seria arriscado afirmar que essa proliferação está em vias de se estabilizar ou regredir. As dificuldades da Rússia com a Chechênia, com o Cáucaso em geral (apesar da fragmentação da URSS, a Federação Russa engloba ainda povos de cerca de cem línguas diferentes e guarda traços dos impérios multiculturais do passado), os movimentos separatistas no seio da Geórgia, do Azerbaijão, o problema basco, indicam que o desejo de criar novos Estados não perdeu atratividade.

\section{A persistência da forma do Estado Nacional}

Tão digno de nota como a multiplicação do Estado-nação é a tendência que tem ele de durar, uma vez estabelecido. Mesmo os falidos, os failed states, nos quais se detecta verdadeira "regressão do Estado" agonizam, mas não desaparecem. Até na mais extrema situação imaginável de falência de Estado, a da Somália, sem governo central há mais de uma década e partilhada por senhores feudais, mantém-se a aparência, se não a realidade do Estado Nacional.

A preferência pela forma de Estado de constituição nacional mais ou menos homogênea condenou ao fracasso de maneira quase invariável todas as tentativas de reunir diversas entidades pequenas e fracas e organizá-las em federações, a fim de melhor prepará-las para a independência. Foram fugazes a Federação das Índias Ocidentais, nas Antilhas, a Federação da Malásia, entre Cingapura e Malásia, as diversas variantes que os colonizadores ingleses e franceses ensaiaram na África Ocidental, na Central, na Oriental.

Da mesma maneira, a jurisdição do grande Império Britânico na Índia se fragmentou primeiro em Índia, Birmânia e Paquistão, dando este origem a Bangladesh após breve e cruenta guerra. Na década de 1990, foi a vez de a Eritréia separar-se da Etiópia, à qual havia sido soldada pela herança da conquista colonial.

Os raros exemplos de fusão - Alemanha, Vietnã - ocorreram somente quando o povo de uma mesma etnia e língua tinha sido dividido por motivos político-ideológicos ligados à guerra fria.

Exemplo ainda mais raro é o da Tanzânia, nascida da reunião de Tanganica, de colonização mista britânico-germânica, com Zanzibar. Mas a verdade é que tudo é excepcional na Tanzânia, a começar pelo privilégio de haver tido como seu pai fundador a figura nobre de Julius Nyerere, que só queria ser co- 


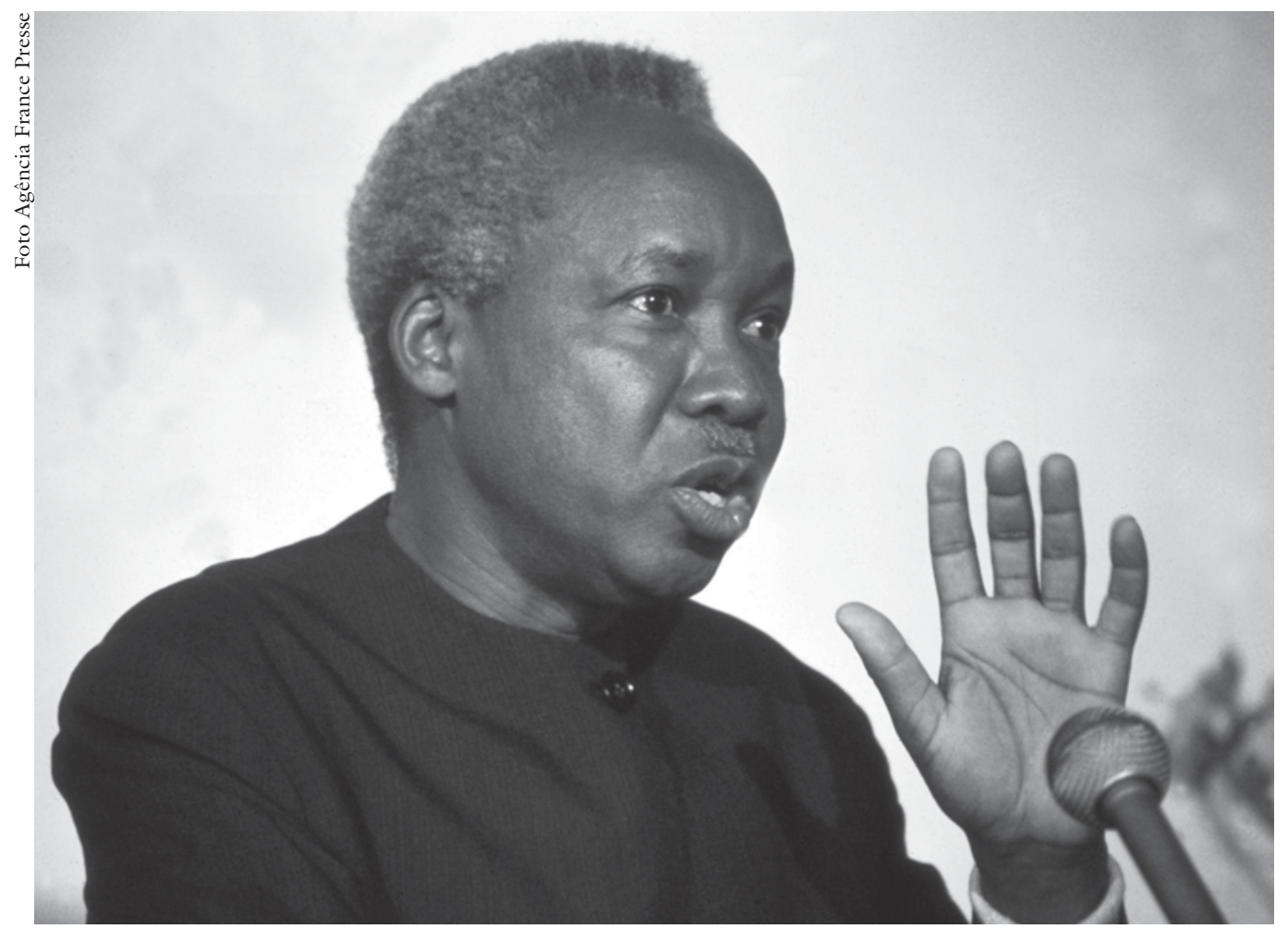

Julius Kambarage Nyerere (1922-1999).

nhecido como Mwalimu, o título que se dá ao professor primário. Além de ter formado um dos poucos países africanos que não tombaram no flagelo do tribalismo, Nyerere foi o único que tomou a iniciativa de limitar seu próprio mandato, retirando-se do poder em plena glória.

Sempre que houve dominação de uma nação por outra, a dificuldade de voltar ao passado é quase intransponível. A união da Suécia e da Noruega dissolveu-se em 1905. Hoje, a Suécia faz parte da União Européia, mas a Noruega não tornou a se reunir indiretamente à Suécia nem mesmo com o anteparo amortecedor da União Européia. Sugestivamente, a Noruega é, junto com a Suíça, o único país europeu cuja população não tem interesse em aderir a Bruxelas.

Aliás, a atitude suíça tem algo a ver com seu pioneirismo na edificação de Estado multicultural, multilingüístico, de início sob forma de confederação, cujo nome conserva e, em seguida, evoluindo para federação. Muitos europeus sonham, para a União Européia, com evolução similar para a qual a Confederação Helvética serviria como modelo em escala menor. Compreende-se que, tendo sido bem-sucedidos no intento, os suíços hesitem em submeter seu modelo, baseado no patriotismo nascido da qualidade das instituições, à tensão resultante de adesão a um sistema europeu que não conseguiu livrar-se da pecha do "déficit democrático".

\section{A variedade e plasticidade do Estado Nacional}

A proliferação de Estados produziu, em nossos dias, perto de duzentas unidades estatais de autonomia maior ou menor, das quais 192 fazem parte 
da Organização das Nações Unidas (ONU), tornando-a a primeira organização internacional de abrangência praticamente planetária. Apenas motivos políticos relevantes impedem que a abrangência se torne total, ao impossibilitar o ingresso de Estados como Taiwan, dotados de todos os demais requisitos necessários.

Para fazer idéia de como se acelerou o processo de criação de Estados Nacionais, é útil lembrar que, dos duzentos centros capazes de decisão relativamente autônoma, nada menos de 150 viram a luz no século XX. A fim de qualificar o número de Estados pela sua real dimensão populacional, vale notar que três quartos da população mundial, isto é, três em cada quatro indivíduos, se concentram em apenas 25 Estados, cada um com população de cinqüenta milhões de habitantes ou mais.

Essa qualificação aponta para outro aspecto, o da diversidade fantástica de dimensões, recursos, poder e características dos Estados Nacionais. Num dos extremos, encontram-se os denominados por George Kennan (1993, p.143-6) de "monster countries", os países monstros. São duas as condições indispensáveis para qualificar como monstros: território continental mais população gigantesca, da ordem de duzentos milhões ou perto disso.

Não basta ter território grande e população modesta (Austrália, Canadá) nem população respeitável em pequeno território (Japão). O exemplo do Japão, país de forte população, mas extraordinariamente homogêneo, põe em relevo o que importa para Kennan: a heterogeneidade. Essa resultaria da combinação de muita gente com um imenso espaço no qual se encontra espalhada. Heterogêneo é tomado no sentido literal: "composto de elementos ou partes de diferente natureza".

O critério aponta para os seguintes membros do seleto clube: os Estados Unidos, a China, a Índia, a ex-URSS e o Brasil. Todos seriam heterogêneos, ou pela evidente diversidade étnica, cultural, lingüística (Índia, Rússia, China, em menor grau) ou pelos agudos contrastes regionais.

O seleto da adjetivação não é aqui valorativo. Para Kennan, o tamanho é mais visto como defeito que qualidade. Voltando a Rousseau e ao tradicional argumento suíço de que democracia só funciona no interior das pequenas comunidades onde todo mundo se conhece, ele se interroga sobre o efeito do tamanho no teor de democracia. Veja-se o pessimismo dessa observação: "Há um problema real em saber se o tamanho ou grandeza (no original, bigness) numa entidade política não é um mal em si mesmo, abstraindo das políticas perseguidas em seu nome" (ibidem, p.143).

Nas antípodas dos monstros se localizam os micro-Estados, os países em miniatura, que sobrevivem da emissão de selos postais, do aluguel do nome à internet (vantagem surgida com a globalização) ou das facilidades que oferecem como paraísos fiscais. Entre os dois pólos, estende-se uma extensa gama intermediária de Estados de variedade quase inumerável em matéria de dimensões - minúsculas, pequenas, médias - de situações geográficas também de diversidade notável - pequenas ilhas, enclaves sem acesso ao mar -, principados re- 
manescentes da Idade Média, cidades-Estados, ex-grandes potências européias reduzidas a países medianos.

A única coisa que têm em comum entidades tão diversas é a opção pela modalidade de Estado Nacional nascida em fins do século XVIII. Fala muito em favor da plasticidade e utilidade desse tipo de organização a variedade de situações a que serve. O Estado Nacional adaptou-se tanto às necessidades de mastodontes, como a China e a Rússia, quanto às de ilhas insignificantes do Pacífico, como Vanuatu e Tovalu. Até a Igreja Católica jamais abriu mão da garantia de relativa autonomia que lhe confere o Estado do Vaticano. A virtual unanimidade da escolha recomenda sobriedade nas profecias de que ele esteja sofrendo crise terminal e será em toda a parte descartado por algo melhor.

\section{Os desafios do Estado Nacional no século XXI}

Constatar o invejável sucesso histórico que teve a invenção do Estado Nacional não significa desconhecer que ele se encontra submetido a tensões e desafios que, ao menos na Europa, podem eventualmente conduzir à sua substituição por configuração pós-nacional. Generalizar sobre tais tensões é arriscado, pois somente algumas delas são, de fato, inéditas, tendo a ver com o avanço da globalização. Mesmo essas, embora se façam sentir em todo o mundo, não afetam a todos com igual intensidade.

Outras tensões, como as criadas pelas ações globais, até certo ponto fora do controle dos Estados, de parte de atores não-estatais - organizações não-governamentais, religiões, partidos, movimentos políticos, terroristas, redes de crime internacional organizado - não são propriamente novas, apesar de se terem multiplicado e adquirido envergadura desconhecida no passado.

Há, por fim, fatores relevantes em específicas circunstâncias de espaço e tempo. Em relação à unificação européia, é o caso de motivos como o de evitar a repetição das guerras mundiais, de fazer frente à pressão soviética durante a guerra fria, criar massa crítica capaz de manter para a Europa status comparável ao dos Estados Unidos ou dos gigantes asiáticos em ascensão etc.

Convém não perder de vista que, enquanto, no contexto europeu, razões desse tipo pesam no sentido de superar o Estado Nacional, as diferenças de tempo histórico não permitiram, em outros continentes, nem sequer atingir o cobiçado nível mínimo de Estado-nação funcional. A tese do declínio do Estado Nacional não tem, com efeito, a mesma atratividade para quem tenta ainda integrar a população indígena boliviana numa estrutura estatal nacional, ultrapassar as divisões tribais por meio de governos nacionais na África ou obter o reconhecimento estatal para a entidade palestina.

A literatura recente tende a considerar mais importantes os desafios que decorrem da globalização para certas funções tradicionais do Estado Nacional. O poder de controle estatal se veria erodido não tanto por meio da intensificação sem precedentes das transações econômico-comerciais across the border, de um lado a outro da fronteira, que continuariam sob a supervisão governamental. 
O fenômeno ocorreria, sobretudo, pelos contatos ou transações transborder, por cima ou além das fronteiras, como se elas tivessem se tornado irrelevantes.

É o que sucederia com a estonteante explosão das comunicações e contatos pela internet e as ondas eletrônicas, conduzindo à uniformização de padrões culturais e políticos. Ou por meio das transações do comércio eletrônico, nos exemplos de compra e venda de bens intangíveis, encomendados e downloaded por computador, pagos em paraísos fiscais, que escapam por completo à vigilância das autoridades nacionais. Não se esquecendo do explosivo aumento, desvinculado da economia real, das operações financeiras e cambiais por meio da internet.

A essas modalidades de transações novas se somaria a atividade multiforme das empresas transnacionais atuantes em dezenas de países, capazes de se delocalizarem em busca da vantagem de custos operacionais mais baixos, dotadas de recursos superiores à maioria das economias nacionais. $\mathrm{O}$ somatório de tais fatores acarretaria, por toda a parte, a exacerbação de impiedosa concorrência, com perigos para as conquistas e garantias do Estado de bem-estar social.

Habermas (2001, p.84) é um dos autores que chamam a atenção para o fato de que: "desde o final dos anos 1970 [...] essa forma de institucionalização, baseada no estado nacional, se encontra cada vez mais sob a pressão da globalização". Para ele, a expressão "globalização" evoca "em contraposição ao lastro territorial do estado nacional, a imagem de rios transbordando que minam os controles de fronteira e podem levar à destruição do 'edifício' nacional" (ibidem, p.85-6).

De modo sistemático, passa em revista como a globalização afeta: “a) a segurança jurídica e a efetividade do estado administrativo; b) a soberania do estado territorial; c) a identidade coletiva; e d) a legitimidade democrática do estado nacional" (ibidem, p.87-102).

A concorrência globalizada torna crescentemente inviável defender o estado social e democrático europeu exclusivamente no âmbito do Estado Nacional. Diante dessa dificuldade, a resposta de Habermas favorece a construção de uma Europa de configuração pós-nacional, fundamentada no "patriotismo constitucional" de uma Carta aprovada por base de legitimidade ampliada.

Cita aprovadoramente Carl Offe: "Um fortalecimento da capacidade de governo das instituições européias não é pensável sem o aumento de sua base de legitimação formalmente democrática” (apud Habermas, 2001, p.125). Já na "Introdução", declara de modo lapidar:

Vejo uma alternativa normativamente satisfatória [...] apenas no aperfeiçoamento federalista de uma União Européia capaz de agir em termos de política social e econômica, que então poderá dirigir o olhar para o futuro de uma ordem (mundial) cosmopolita, sensível às diferenças e socialmente equilibrada. (ibidem, p.2)

Não é este o lugar para discutir os obstáculos que vem encontrando, na prática, tanto a aprovação de uma constituição européia por ampla base de le- 
gitimação quanto a determinação e eficácia da União Européia para evitar o desmantelamento do estado social. Não obstante, a posição de Habermas é a que melhor sintetiza o ideal de uma configuração pós-nacional como única esperança de deter o ímpeto de globalização desumanizadora.

\section{As vicissitudes da globalização}

Ao mesmo tempo, cabe uma palavra de cautela. As advertências sobre os perigos da globalização tiveram sua voga no momento em que essa parecia onda avassaladora que levaria tudo de roldão. Na década de 1990, especialmente em sua primeira metade, era essa a impressão predominante. Estava fresco o impacto da queda do Muro de Berlim, do fim do socialismo real, da desintegração da União Soviética. A convergência rumo à economia de mercado e à democracia representativa inspirava anúncios prematuros como o do "fim da História".

O ponto mais alto da maré foi em meados dos 1990, quando se funda a Organização Mundial do Comércio (OMC) em 1994, pouco antes do início das crises monetárias e financeiras do México-Argentina (1994-1995), da Ásia (1997), da Rússia e Brasil (1998). Desde então, vários fatores contribuíram para alterar a percepção: o contágio das crises, o estouro da "bolha eletrônica" (20002001), o movimento antiglobalização, o impasse nas três grandes negociações que completariam o quadro institucional de uma economia globalizada.

Esses três processos visavam fechar o círculo da unificação econômica planetária nos setores fundamentais da economia: finanças (a abertura plena da conta capital da balança de pagamentos pelo FMI); investimentos (o frustrado Acordo Multilateral de Investimentos, na OCDE); comércio (a abolição restante de todas as restrições ao comércio pela OMC).

Dessas três, as duas primeiras saíram da agenda (a não ser os investimentos nos acordos bilaterais e regionais) e a última foi retomada pela OMC, sob a forma diluída da Rodada Doha.

O golpe mais sério veio, contudo, de direção inesperada: da periferia do sistema, do Afeganistão. O atentado terrorista de setembro de 2001 introduziu fase nova nas relações internacionais, trazendo de volta as preocupações obsessivas com a segurança. A imediata conseqüência foi a afirmação do Estado sobre o mercado, o prevalecimento do político e do militar sobre o econômico, a lógica do reforço, não da abolição, dos controles das fronteiras.

Sintoma revelador da mudança é que, em contraste com Clinton, o presidente George W. Bush praticamente baniu do discurso a palavra globalização. O que é natural, pois um governo de cunho acentuadamente nacionalista e unilateral como o seu possui escassa afinidade com o internacionalismo da globalização. Os problemas atuais - guerras intermináveis no Iraque e Afeganistão e crise econômica de proporções inquietantes no seio da economia-centro do mundo globalizado - dificultam a volta de condições propícias a um novo auge da globalização. 


\section{Ambigüidades da globalização}

Acresce que antes, quando se falava em globalização, entendia-se a variedade anglo-saxônica disseminada pelos governos Clinton e Blair, fontes principais das pressões para a liberalização de normas e regimes nas negociações mundiais ou no interior da União Européia.

Hoje começa a afirmar-se, cada vez com mais nitidez, variante de globalização com sotaques chinês, indiano, asiático, árabe, brasileiro. $\mathrm{O}$ primeiro impacto dessa transformação nos países desenvolvidos aparece no apetite pela abertura comercial, que esmorece diante do que seriam os medos dominantes no comércio mundial, de acordo com fórmula simplificadora: medo da indústria da China, dos serviços off-shore da Índia, da agricultura do Brasil.

Além de produtos competitivos, os países emergentes passam também a exportar investimentos, seja diretamente pela ação de suas empresas internacionalizadas seja pelos fundos soberanos possibilitados pelo acúmulo de reservas. Contra isso já se manifestaram reações em setores sensíveis, como o dos investidores de Dubai, forçados a desistir do controle de empresa portuária nos Estados Unidos e de estatal petrolífera chinesa, obrigada a recuar na compra de refinaria americana.

Mais recentemente, vem também suscitando início de preocupação o socorro proporcionado por fundos soberanos da China, de Cingapura, de países árabes às empresas financeiras ianques fragilizadas pelas perdas no mercado de hipotecas, mediante aquisição de parte do capital dessas firmas. Incipiente, a preocupação poderá crescer ou não se as operações se amiudarem ou chegarem a envolver transferência de controle.

É possível que, conforme ocorreu na Grã-Bretanha algum tempo atrás, tudo não passe de reação inicial, sem maiores desdobramentos, mas só o tempo dirá como a nova tendência irá afetar as pressões para a liberalização de normas.

De todo modo, a evolução atual serve para qualificar os termos categóricos com que se afirmava que o desmantelamento dos controles estatais era exigência irresistível da natureza da globalização. Vê-se agora que, ao menos em parte, esse aparente determinismo não passava de disfarce ideológico para a ação de governos de Estados Nacionais poderosos como os dos Estados Unidos e da Inglaterra.

Dito isso, não se deseja negar que a redução dos controles é parcialmente o resultado de profundas forças econômicas ou tecnológicas mais ou menos independentes da vontade dos governos. Tal é o caso das tendências impulsionadoras da globalização: a internacionalização do processo de produção, sua fragmentação por locais geograficamente distantes uns dos outros em razão da economia de custos, a transnacionalização das empresas que operam o processo e criam as redes de distribuição, os avanços em eletrônica, telecomunicações, transportes, que o tornam factível.

Essas forças continuam ativas e operantes. O que se alterou foi o contexto político, ideológico, de segurança dentro do qual se movem. Em suma, não é 
exagero sustentar que a globalização não sofreu retrocesso, mas perdeu por enquanto o que os americanos chamam de momentum, isto é, o ímpeto, o ritmo acelerado ostentado há doze ou quinze anos.

\section{Outras ambigüidades}

Para compreender a situação com que se defronta o Estado Nacional, convém ter presentes duas observações: 1. nem tudo se reduz à globalização, existindo em ação outras forças no domínio político e de segurança; 2. os efeitos de tais forças são ambivalentes, não se exercendo necessariamente no sentido do enfraquecimento das capacidades e possibilidades do Estado-nação.

Com outras palavras, é o que diz Giddens (1996, p.67): “a perda de autonomia por parte de alguns Estados ou grupos de Estados com freqüência coincidiu com o aumento na de outros, como resultado de alianças, guerras ou mudanças políticas e econômicas de vários tipos”.

A mais importante dessas mudanças tem sido a gradual emergência, desde a Segunda Guerra Mundial, de um sistema de segurança coletiva encarnado na mais universal de todas as organizações internacionais da história, a Organização das Nações Unidas. Sem embargo de notórias deficiências - haja vista a invasão do Iraque, sem aval do Conselho de Segurança -, não se pode negar que os países sem força militar estão mais protegidos do que em momento algum do passado contra agressões, invasões ou anexações. O sistema universal é reforçado de modo considerável por alianças regionais, como é o caso da mais conhecida delas, a Organização do Atlântico Norte (Otan).

A combinação das novas oportunidades criadas pela globalização com o acrescido sentimento de segurança explica o reaparecimento de cidades-Estados como Cingapura e Hong Kong, esta última mesmo após seu retorno à China sem perder algumas de suas anteriores características. Certos Estados petrolíferos do Golfo, como os Emirados Árabes Unidos e o Quatar, não estão muito longe desse padrão: sem agricultura, com território exíguo ou desértico, especializam-se cada vez mais na criação de sofisticados e eficientes centros avançados de prestação de serviços ou nós de comunicação, modelo do qual Cingapura e Dubai são exemplos conhecidos.

Seria difícil imaginar em nossos dias a repetição da desenvoltura com que Napoleão suprimiu a Sereníssima República de Veneza ou com que ele ou as forças revolucionárias francesas eliminaram outras veneráveis relíquias como a República de Gênova e a de Genebra. E, no entanto, o que defende as unidades inermes contra predadores poderosos, a não ser o sistema da $\mathrm{ONU}$, do direito internacional e a autocontenção dos poderosos?

No antigo regime territorial europeu, no qual as potências se engrandeciam por meio de conquista de território, entidades riquíssimas como Luxemburgo (quatrocentos mil habitantes) ou a Noruega (quatro milhões de habitantes) só escapariam da anexação se as cobiças dos fortes se equilibrassem e cancelassem mutuamente. 
Atribui-se ao barão de Rio Branco a frase: “Território é poder”. O território será ainda talvez uma das bases do poder. Já não parece tão evidente, contudo, que algumas das conseqüências associadas ao poder e ao tamanho, especialmente a maximização do bem-estar, da "felicidade" dos cidadãos, buscada pelos revolucionários da independência americana ou por Saint-Just, derivem ou dependam do território ou da força. Confirma-se, desse modo, o ceticismo de Kennan a respeito dos países-monstros.

Todos os índices classificatórios de desenvolvimento humano, renda per capita, longevidade, ausência de corrupção e criminalidade colocam nos primeiros dez postos países pequenos, tais como Finlândia, Noruega, Dinamarca, Suécia, Suíça, Luxemburgo, Nova Zelândia, Cingapura, Islândia, muito antes não só do gigantesco Estados Unidos, mas até dos intermediários Alemanha, Reino Unido, França.

Pode-se acaso sustentar que a globalização é mais ameaça que oportunidade para Cingapura ou Dubai? Ou que Noruega e Luxemburgo, invadidos por Hitler, e a Finlândia, agredida por Stalin, estivessem melhor no passado, até relativamente recente, digamos em 1939 ou 1940?

O que demonstram esses exemplos é que a segurança dos cidadãos, sua prosperidade ou bem-estar, outrora mais bem garantidos pelo poder do Estado, passaram a estar ao alcance de estruturas menores, fracas em tese, desde que presentes condições internacionais que as complementem e reforcem, como as vigentes no segundo pós-guerra.

Tome-se o episódio da secessão dos eslovacos da Checoslováquia, a fim de aderir em separado à União Européia. Na década de 1920 ou 1930, a secessão seria vista como enfraquecimento intolerável e resistida pela força. Desta vez, tudo se cumpriu tranqüilamente, uma vez que a segurança de cada um dos dois povos iria depender da Otan e, portanto, em última instância, dos Estados Unidos, ao passo que a prosperidade era promessa não mais do restrito mercado doméstico, mas sim da adesão ao muito mais sedutor mercado europeu.

A separação da Eslovênia e, mais tarde, de Montenegro obedeceu à mesma lógica: a certeza de que, sem o peso dos sérvios, seria mais fácil a esses dois antigos integrantes da ex-Iugoslávia serem admitidos à União Européia e à Otan. Em todos esses casos, troca-se um Estado bi- ou multinacional por estruturas incomparavelmente mais atrativas como a União Européia em matéria de potencial econômico e prestígio político e a Otan para as necessidades de segurança.

\section{Conclusões}

Dois complexos organizacionais, originários da história européia e com poucos paralelos em períodos anteriores ou cenários culturais distintos, tiveram significação especial no desenvolvimento da modernidade: o Estado-nação e a produção sistemática de tipo capitalista. Após essa constatação, Giddens (1996, p.174) observa: "Se os dois se propagaram pelo mundo inteiro, em estreita conjunção um com o outro, isso se deve, acima de tudo, ao poder que foram capazes de gerar". 
A observação põe em relevo o poder, realidade central do sistema internacional. Central não quer dizer única. Da mesma forma que qualquer outro tipo de organização social, o sistema internacional é caracterizado por situações de colaboração e conflito, percepções de coincidência ou contraposição de interesses dos atores.

Ao possibilitar concentração incomparável de poder, mediante o fortalecimento da capacidade administrativo-fiscal, o domínio territorial e outros traços, o Estado Nacional se converteu na modalidade de organização mais apta a promover a cooperação e arbitrar conflitos.

Desse ponto de vista, Giddens se equivoca ao situar o Estado-nação e a produção capitalista em plano de igualdade, uma vez que a segunda depende muito mais da primeira, do que o reverso. É o que se vê, com evidência que entra pelos olhos, no momento em que a crise econômica americana ganha amplitude. Os mercados e as empresas, supostamente auto-reguláveis, passam a implorar diariamente pelo socorro dos bancos centrais e das ações fiscais dos Estados.

Sob condições de normalidade, pareciam plausíveis as frases de Habermas (2001, p.102) sobre a "impotência devido à globalização" ou a referência à diminuição da capacidade de controle (do Estado) em termos macroeconômicos. Numa hora como a atual, elas soam pouco convincentes.

Pode até suceder que o desdobramento da crise torne inoperantes os remédios do Estado e obrigue a uma longa e penosa cura. Se isso acontecer, será pela gravidade específica dos macrodesequilíbrios que se vêm há tempos acumulando na economia americana, não por alguma debilidade do Estado derivada da globalização.

Acreditou-se no argumento ideológico da autonomia da esfera do econômico, até de seu predomínio sobre o político. Não se percebeu que tendências como a liberalização financeira e a abertura dos mercados aos operadores internacionais eram menos a conseqüência da natureza das coisas (no caso, da globalização) do que de políticas perseguidas tenazmente pelo Departamento do Tesouro dos Estados Unidos. Em outras palavras, tratava-se de opções políticas, de posições dos mercados financeiros que coincidiam com os interesses da potência mais influente nas negociações internacionais, de mais uma prova, em última análise, do poder do Estado Nacional.

Tanto isso é verdade que, a contrario sensu, os dois êxitos mais espetaculares em crescimento econômico, a China e a Índia, constituem exemplos de desenvolvimento conduzido por Estados Nacionais fortes e mais resistentes à liberalização financeira ou às imposições de empresas transnacionais. Não por acaso, foram essas as duas economias que menos sofreram na crise asiática de 1997.

A realidade de nossos dias é, por conseguinte, a de um mundo formado ainda por Estados Nacionais e caracterizado pelo poder como sua dimensão central. Em sistema assim definido, aquilo que Robert Gilpin (1987) denominou 
de "estabilidade hegemônica" segue vigente, de tal modo que considero basicamente válida a descrição que esbocei do sistema, mais de doze anos atrás.

No texto de então, dizia que a dificuldade de enquadrar a atual configuração de forças num dos protótipos teóricos do passado era a forma pela qual se estabelecia o equilíbrio. Na concepção tradicional, ele provinha dos próprios países componentes e do seu peso específico. O número de atores principais - um, dois ou vários - é que determinaria se a distribuição seria uni-, bi- ou multipolar. Pressupunha-se que cada um dos atores principais fosse um ator de primeira grandeza em cada um dos cenários onde se afirma o poder: militar, econômicofinanceiro, político, tecnológico etc.

Em nossos dias, variam os atores que integram os diversos domínios; os que sobressaem no plano econômico e tecnológico, o Japão, por exemplo, podem não figurar no estratégico-militar. $\mathrm{O}$ equilíbrio vai se produzir, portanto, por meio de jogo mais complexo no qual os atores se contrabalançam pelo concurso de meios diferentes (a dependência financeira atenuando, em certos casos, a hegemonia em armas estratégicas).

E concluía: “Nesse jogo, a vantagem inigualável dos Estados Unidos é serem eles os únicos a poderem jogar, de modo decisivo, em todos os tabuleiros como ator de primeira grandeza: estratégico-militar, político, econômico-financeiro, tecnológico" (Ricupero, 1995, p.118-9), sem esquecer o cultural e de comunicações, aquele no qual se criam os símbolos, imagens, idéias.

Tal predomínio não configura o unipolarismo absoluto, o que os antigos chamavam de monarquia universal. Como a do Império Romano, que não reconhecia iguais, apenas vassalos ou inimigos. Quando Gilpin falava em "estabilidade hegemônica", os Estados Unidos eram vistos ainda como sucessores da Grã-Bretanha vitoriana, a potência ativamente promotora da instauração de ordem política e econômica liberal, como haviam sido na era Roosevelt, ao recriarem os fundamentos da ordem no após-guerra.

O que hoje chama a atenção é ter Washington perdido a capacidade de fornecer a liderança moral e cultural para edificar o difícil consenso multilateral. Essa incapacidade se deve ao unilateralismo de sua ação (a invasão do Iraque é um exemplo) e à perda da legitimidade em matéria de valores decorrente de barbaridades como Guantanamo e a tortura, direta ou terceirizada.

Sobra-lhe, porém, vastíssimo poder de obstruir o consenso quase unânime dos demais. A obstrução vai do regime dos fundos do mar às novas gerações dos direitos humanos sociais, econômicos e culturais. Ela se estende da sabotagem do Tribunal Penal Internacional ao Tratado Contra as Minas Pessoais, culminando na rejeição do Protocolo de Quioto e relutância de negociar novo regime internacional sobre mudança do clima. É sugestivo que, em todas essas questões, a rejeição americana é justificada pelo interesse nacional e a soberania. O paradoxo da situação é que o país inventor original da globalização e seu principal beneficiário também seja o que mais afirma o próprio nacionalismo. 
Muitas dessas decisões unilaterais decorrem da crescente deriva da sociedade dos Estados Unidos para posições conservadoras ou de direita, de escassa influência no sentimento predominante até no restante do mundo ocidental. Tal contraste é perceptível não só na redução da agenda internacional a questões como o terrorismo, a não-proliferação de armas, o Oriente Médio quanto no apego à pena de morte, a atitudes extremas em moral familiar e sexual, ao papel da religião na sociedade etc.

Enquanto esse panorama não se modificar por obra da evolução social e/ ou das eleições, são remotas as possibilidades de aprimoramento da governança global por meio da reforma das instituições da ONU, do FMI, do Banco Mundial e outras organizações, no sentido de maior democratização.

O país com maiores perspectivas de chegar ao status de superpotência em futuro previsível, a China, tem dado prioridade quase exclusiva a seus objetivos de ascensão econômico-comercial e a interesses estratégicos nacionais (Taiwan, Tibete). Em temas de vital importância para o planeta como o aquecimento global, comporta-se com o mesmo sacro egoísmo dos Estados Unidos.

Nesse quadro de nacionalismos tradicionais, a União Européia faz figura singular pela estrutura pós-nacional e a qualidade relativamente mais esclarecida de sua liderança internacional (em mudança do clima, por exemplo). Sua estrutura é diversa das velhas confederações, que começavam pela delegação da defesa e da diplomacia ao poder central, justamente os setores ainda mais controlados pelos Estados na União Européia. Começou-se aqui pelo mais especificamente doméstico: a política agrícola, o mercado comum, as regras de concorrência, a Corte Européia, a moeda comum, o Parlamento.

Em vez de copiar modelos do passado, os europeus souberam criar algo novo em termos de organização pós-nacional, como fizeram ao inventar o Estado Nacional. A integração européia vai ao fundo das coisas e se baseia nos valores. O candidato à adesão passa por longo processo pelo qual tem de recriar-se a si mesmo, adaptando suas leis e instituições ao patrimônio consolidado e adotando os padrões europeus mínimos em direitos humanos, ecologia, vida democrática.

Em contrapartida, a convergência dos novos membros mais pobres com a média da renda comunitária é auxiliada por transferências financeiras de vulto capaz de operar milagres como os da Espanha e da Irlanda. É sensível o contraste com os acordos de livre comércio de Washington, que se restringem ao suposto potencial do comércio para efetuar a convergência dos níveis de renda.

A diferença decorre da natureza mesma do processo que, no caso europeu, vê os candidatos como herdeiros da mesma história e civilização e futuros co-cidadãos com iguais direitos. A ajuda financeira, recusada pelos americanos em seus acordos, é mecanismo de solidariedade intra-regiões, até agora símbolo da coesão dos Estados Nacionais. É ele que permite à União Européia transpor ao nível pós-nacional esse atributo do Estado Nacional, de ser a "mais alta liga 
social conhecida até hoje com a capacidade de tornar aceitável o sacrifício da redistribuição" (Offe apud Habermas, 2001, p.129).

$\mathrm{O}$ aprendizado da solidariedade de cidadãos, expandida em dimensão européia, estaria na linha da experiência histórica da Europa. Segundo Habermas, tal experiência, até mesmo pelas lições extraídas dos freqüentes conflitos e desastres, teria contribuído para a superação do particularismo e das perspectivas estreitas, a tomada de distância em relação às animosidades, a tolerância e a institucionalização das disputas.

Seu resultado líquido seria o de ter marcado a "auto-compreensão normativa da modernidade européia com um universalismo igualitário, que pode facilitar [...] a transição para [...] uma democracia pós-nacional" (Habermas, 2001, p.130-1).

Um magnífico "mito criador", dirão os mais céticos. Desde que se introduzam algumas qualificações - uma delas é a reação européia aos imigrantes islâmicos, africanos, aos extracomunitários em geral - não será exagero dizer que o mito guarda suficiente ligação com a realidade para tornar o modelo europeu mais atrativo do que outros. A posição mais esclarecida da União Européia em muitas questões internacionais, a começar pela do aquecimento global, justifica afirmar que ela ajuda a edificar "ordem cosmopolita sensível às diferenças e socialmente equilibrada".

Talvez caiba, como conclusão, evocar imagem que pode servir como símbolo das diferenças. No início de 2008, a televisão mostrou como se ergue, no Oeste americano, soberbo muro de concreto para separar essas terras (outrora mexicanas) do México, embora este último seja parceiro dos Estados Unidos em acordo de livre comércio há quase quinze anos. Ao mesmo tempo, além-Atlântico, eram removidos os postos de fronteira que separavam os europeus ocidentais dos seus recentes associados do Elba à fronteira com a Rússia. Desmantelava-se, assim, em definitivo, aquilo que um dia Churchill comparou a uma Cortina de Ferro que baixava, inexorável, de Sttetin a Trieste, do Báltico ao Adriático.

Referências bibliográficas

GIDDENS, A. The Consequences of Modernity. Cambridge: Polity Press, 1996.

GILPIN, R. The Political Economy of International Relations. Princeton: Princeton University Press, 1987.

HABERMAS, J. A constelação pós-nacional. Ensaios políticos. Trad. Márcio SeligmanSilva. São Paulo: Littera Mundi, 2001.

KENNAN, G. F. Around the Cragged Hill: A Personal and Political Philosophy. New York: W. W. Norton \& Co., 1993.

RICUPERO, R. Visões do Brasil. Rio de Janeiro: Record, 1995. 
RESUMO - Apesar da literatura sobre o recente enfraquecimento de funções básicas do Estado Nacional por obra da globalização, o Estado-nação vem demonstrando admirável resiliência, isto é, flexibilidade e capacidade de adaptação às mudanças. Partindo da perspectiva das relações internacionais, o artigo realiza levantamento da geografia política do mundo contemporâneo, indicando as razões que levaram à criação, no século XX, de nada menos de 150, do total de cerca de duzentos Estados existentes. Analisa o caráter ambivalente dos fatores de mudança, nem sempre no sentido do enfraquecimento do Estado, e se detém no caso da União Européia, única exceção de êxito na construção, ainda incompleta, de configuração pós-nacional.

PALAVRAS-CHAVE: Nação, Nacionalismo, Estado Nacional, Sistema internacional, Globalização, Configuração pós-nacional.

ABSTRACT - Notwithstanding recent studies about the alleged weakening of some basic functions of nation-states on account of globalization, national states have been showing remarkable resiliency, that is, flexibility and adaptability to change. Starting from the perspective of international relations, the article undertakes a review of contemporary world's political geography, pointing out some of the reasons that explain the creation, during the $\mathrm{XX}^{\text {th }}$ century, of 150 out of a total number of 200 existing national states. It analyses the ambivalent nature of some of the forces for change, not always towards national state weakening, and devotes special attention to the European Union, the only example of a still unfinished construction of a post-national configuration.

KEYWORDS: Nation, Nationalism, National State, International system, Globalization, Post-national configuration.

Rubens Ricupero é diretor da Faculdade de Economia da Fundação Armando Álvares Penteado (FAAP). Foi secretário-geral da Conferência das Nações Unidas para o Comércio e Desenvolvimento (Unctad). @ - mpricupero@uol.com.br

Recebido em 12.2.2008 e aceito em 15.2.2008. 